\title{
National Bank for Agriculture and Rural Development (NABARD)
}

\author{
Mamoni Das
}

Guest Faculty, Department of Political Science, J.N.R.M, Port Blair-744101

\begin{abstract}
Indian economy is agricultural economy and real India lies in villages. Without the development of the rural economy, the objectives of economic planning cannot be achieved. Hence, banks and other financial institutions are considered to be a vital role for the development of the rural economy in India. NABARD are playing a pivotal role in the economy development of the rural India. In the Indian context rural development assumes greater significance as nearly $70 \%$ of its population lives in rural areas. Most of the people living in rural area draw their livelihood from agriculture and allied sectors. Such areas are distinct from more intensively settled urban and suburban areas. Life styles in rural area are different than those in urban areas, mainly because limited services are available. Governmental services like law enforcement, schools, fire departments may be distant, limited in scope, or unavailable. Rural development is a national necessity and has considerable importance in India. The main objective of the rural development programme is to raise the economic and social level of the rural people. National Bank for Agriculture and Rural Development (NABARD) is set up as an apex institution by the Government of India with the main objective of providing and regulating credit and other facilities for the promotion of rural development. It is a single integrated organisation which looks after the credit requirements of all types of agricultural and rural development activities. The present study is a modest attempt to the credit potential for agriculture during the year 2021-22. The study covered aspects such as functions, objectives, management and organizational structure, sources of funds, activities achieved, loan assistance to various institutions, Methodology
\end{abstract}

for preparation of potential linked credit plans (PLPs) and Development Projects in Andaman and Nicobar Islands.

Keywords: NABARD, Rural Development, RBI and SHGs.

\section{INTRODUCTION}

Agriculture is the core sector of the Indian economy. It accounts for $21 \%$ of GDP and about two-thirds of the population is dependent on this sector. It is thus rightly said that agriculture is the backbone of our economy and its prosperity can largely be responsible for the well being of the entire economy. The vigorous growth of agriculture sector demands adequate flow of finance. Farm finance has a place of pride in the agro-socioeconomic development of the country both at micro and macro levels. Its catalytic role strengthens the farming business and augments the productivity of scarce resources. Application of new technological inputs obtained through farm finance helps boost of agricultural productivity. Farm finance can also contribute to reduction in regional economic imbalances. Thus, the role of farm finance in strengthening and development of both input and output markets in agriculture is crucial and significant.

Agricultural development was given high priority in the past fifty years and especially under various Five year plans. Bank credit is avail- able to the farmers in the form of short term credit for financial crop production programmes and in the form of medium-term/ long-term credit for financing capital investments in agriculture 
and allied activities like land development including purchase of land, minor irrigation, farm mechanization, diary development, poultry animal husbandry, fisheries, plantation and horticulture. Loans are available for storage, processing and marketing of agricultural produce.

Now a days the long term and short term credit needs of these institutions are also being met by National Bank for Agricultural and Rural Development (NABARD). It is the evolution of agricultural finance.

\section{NATIONAL BANK FOR \\ AGRICULTURE AND RURAL DEVELOPMENT (NABARD)}

National Bank for Agriculture and Rural Development (NABARD) came into existence on 12 July, 1982. NABARD was established for providing credit for promotion of agriculture, small-scale industries, cottage and village industries, handicrafts and other allied economic activities in rural areas with a view to promoting integrated rural development and securing prosperity of rural areas.

\section{SCHEMES/ PROGRAMMES OF NABARD:}

\section{a) Self-help Group (SHG) Bank Linkage Programme:}

The SHG-Bank Linkage Programme is a major plank of the strategy for delivering financial services to the poor in a sustainable manner. It was started as an Action Research Project in 1989, which was the off-shoot of a NABARD initiative during 1987 through sanctioning Rs.10 lakh to MYRADA as seed money assistance for experimenting Credit Management Groups. The experiences of these early efforts led to the approval of a pilot project by NABARD in 1992. The pilot project was designed as a partnership model between 3 agencies viz., the SHGs, banks and NGOs.

\section{b) Kishan Credit Card (KCC):}

KCC Scheme was introduced in 1998-99. It was launched to provide timely and adequate supply of Short Term (ST) credit from the banking system to the farmers to meet their crop production requirements in a flexible, hassle free and cost effective manner. The objective was to provide an instrument, which would allow farmers to purchase agricultural inputs such as seeds, fertilizers, and pesticides and also withdraw some cash for meeting their production-related requirements.

\section{c) Farmers' Club:}

The programme aims to organize farmers to facilitate accessing credit, extension services, technology and markets. NABARD encourages banks to promote Farmers' Club in rural areas under the Farmers' Club Programme, earlier known as "Vikas Volunteer Vahini (VVV) Programme". Farmers' Club are grass root level informal forums of farmers. Such clubs are organized by rural branches of banks with the support and financial assistance of NABARD for the mutual benefit of the banks concerned and the village farming community/rural people.

\section{d) District Rural Industries Project:}

NABARD on a pilot basis had launched an integrated area based credit intensification programme in collaboration with Government, Banks and other development strategies with focus on district known as District Rural Industries Project during 1993-94 with a view to evolving a role model for rural industrialization.

\section{e) Rural Infrastructure Development Fund (RIDF):}

RIDF is a major source of fund for the development of infrastructure in the rural area of the State.

\section{f) Watershed Development:}

The objective of developing watersheds is to significantly mitigate the drought induced distress of farmers in the area. NABARD anchors 4 types of 
watershed development programmes in the country. These programmes are: IndoGerman Watershed Development Programmes, Participatory Watershed Development Programme, Prime Minister's Package in 4 states and Integrated Watershed Development programme.

\section{Role and Function}

NABARD is now the foremost and the apex institution in the field of providing credit for agriculture and other rural activities that involve financing. It is also the institution that is accredited with matters relating to policy, planning and other operations relating to agricultural economic financing.

The preamble of the NABARD Act mentions the following objectives for the rural based bank, its primary function should be to promote agriculture, provide credit aid small scale industries whether cottage or village handcrafts and other rural crafts and activities that are associated with it. The prosperity of rural areas is it most major concern.

\section{In brief NABARD performs the following functions:}

NABARD not only improves the absorptive of the credit delivery system to the rural areas while performing the task of monitoring and the formulation of rehabilitation schemes to rescue the rural farmers but it also adds the initiatives of training personnel to further its objective so that well trained personnel are equipped with information and methods to help the rural sector majority of which is un educated.

The rural bank also maintains its collaboration with the state and other bodies in order to maintain its objectives such as the Government of India the State Governments and the RBI itself. The development at the grassroots level is maintained through this association various state bodies. The collaboration also involves major policy formulation as well.
The bank is also responsible for preparing annual credit plans for all rural districts in the country and these very plans are the ones that form the base for the credit plans for all rural financing and their institutions annually. It also monitors the projects that are refinanced by it and it evaluates them as well. NABARD not only maintains its financial and economical role but also performs social duties as well by promoting research in fields of rural banking, innovations in agriculture and rural development as well.

\section{Objectives of NABARD:}

NABARD being the apex bank for rural development is responsible for the following categories of rural economy such as credit for the promotion of Agriculture, small scale industries which also include cottage and village industries. It also formulates policies in matters relating to planning operations and other allied an associated economic activity relating to rural areas. The bank also serves the function of long term and short term refinancing for institutional credit for the activities in rural agriculture. At the approval of Central Government, the bank can also provide direct lending to any institution.

It becomes very important to maintain a relation and a constant link to the Reserve Bank of India in order to perform its functions fluidly.

\section{Organizational Structure of NABARD:}

The bank consists of a Board of Directors at the very top to maintain affairs and policy decisions who maintain control below them is an elected Chairman who is assisted by a Managing Director. There are two Executive Directors below the Managing Director who handles affairs.

There are 26 Head Office Departments across the country which is then pared with 28 Regional Offices and 6 Training Establishments. 
There is also a Special Cell Suboffice at Srinagar in Jammu and Kashmir and 391 District Development Offices.

\section{Major Activities}

The apex rural bank is thus responsible for recognizing Potential Linked Credit Plans and thus realizing the identification of exploitable potentials under agriculture and other activities that may be allied with it and that may promote agricultural development through the credit it may provide. The bank impressively also has the ability to provide loan in matters relating to rural infrastructure and institutional building to the State Government, Non-governmental organizations and also Panchayati Raj Institutions [PRIs).

The rural poor in the past found it very difficult to gather funds or loans to finance their activities what NABARD does it makes the usual non-credit worthy farmer worthy enough to receive funds from it, the apex rural bank provides formal banking services to the rural poor who find these kind of funds un reachable in the past. The bank does this by creating a supplementary credit delivery strategy which is cost effective in its operation which is promotes Self Help Groups (SHGs).

There are areas that may receive higher percentage of rainfall than other regions which depend on the rain for agriculture. The bank promotes participatory watershed development which in turn enhances the productivity and the profitability of rain fed agriculture which becomes sustainable. In this way the rain water harvested is never gone to waste and can be also used during dry spells.

The apex bank also conducts through its officials on site inspection of cooperative banks to keep a check on them and also on the Regional Rural Banks or RRBs as well and off site surveillance over the health and functioning of the cooperatives and the RRBs. This check keeps a mandatory check on these organization in order to keep them functioning efficiently in order to perform the functions they were created for and not let them have the notion that them being established in the rural area will not be an excuse for non performance.

\section{NABARD launches development projects in Andaman \& Nicobar Islands}

The National Bank for Agriculture and Rural Development (NABARD) has launched development projects in Andaman \& Nicobar Islands worth Rs. 44 lakhs.

These projects aim at strengthening the concept of Atmanirbhar Bharat through rural entrepreneurship. The projects by NABARD will include the formation and development of Self-Help Groups, SHG.

In order to make Atmanirbhar Bharat a reality, the development bank has also been providing a platform for the sales of local products by financing the Rural Haats in Gram Panchayat.

\section{NABARD's projects in A\&N Islands:}

- Under the development projects launched by NABARD in Andaman \& Nicobar Islands, skill development of Self-Help Group members will be taken up to promote rural entrepreneurship at the micro-level.

- The bank will conduct 385 village-level programmes and will provide training to the leaders of the newly formed SHG with the sum of more than Rs. 10 lakh.

- In Little Andaman, women attached to SHG's will be Bamboo Handicraft making and Mushroom cultivation.

- A 4-month long training programme for the tour and travel agents in Swaraj Deep has also been listed in the schedule.

- A yearly Micro-Entrepreneurship Development Programme will also be carried out for 150 members of SHG's in Mayabunder in Middle Andaman.

- NABARD's additional projects in Andaman \& Nicobar:

- The development bank has also tied up with the Centre of Agriculture Research Institute (CARI) for conducting the 
agricultural programmes with an amount of Rs. 20 lakh.

- Additionally, in order to provide a platform for sales of the local products, the bank has also been financing Rural Haats in Gram Panchayats. For this, total Rs. 7.6 lakhs have been released to establish one such Haat in Namunaghar Panchayat of South Andaman.

\section{Highlights of developments/initiatives by NABARD}

In the UT, NABARD has supported variety of programs ranging from transfer of technologies through ICAR-CIARI and KVKs; nurturing of FPOs, skill Development Programmes (SDPs); Micro Entrepreneurship Development Programmes (MEDPs); Rural Haats, Rural Marts; support in formation and credit linkage of SHGs/JLGs; capacity building of personnel in Co-operative banks; financial inclusion initiatives; Research \& Development, etc.

\section{Thrust Areas for 2021-22}

During the year 2021-22 it is proposed to give major thrust on nurturing and strengthening the FPOs, Agriculture Infrastructure Fund, PACS as MSC, Derisking Farm Income through Integrated Farm Models, Financial Inclusion, and Tribal Development.

Banking Plan with Credit Linked Subsidy Schemes with Interest Subvention and Credit Risk cover plans, Climate Change Adaptation, Addressing Problems of Agriculture and Allied Activities through Solution based projects implemented in partnership with CIARI and KVKs.

\section{Banking Profile}

* State Bank of India is the Lead Bank of the Union Territory.

* There are 22 CBs with 67 Branches, 1 State Cooperative Bank with 41 branches and 46 affiliated PACS catering to the banking needs of the Islanders. Out of 154 branches including PACS, 29 of them are in the semi-urban areas, 36 in urban areas and 89 are in the rural areas.

* There are only 3 Business Correspondents (BC)/Business Facilitators (BF) appointed by the Commercial Banks.

* Of the 154 bank branches, commercial banks and ANStCB including the PACS catered to an average of 8 villages covering 1411 households and 26 villages covering 4362 households, respectively.

* There are 12 Financial Literacy Centers set up in the Islands, of which 5 are in South Andaman, 4 in North \& Middle Andaman and 3 in Nicobar District. Of these, 7 FLCs have been set up by ANStCB with the financial support from NABARD at Diglipur, Mayabunder, Rangat, Nancowry, Campbell Bay, Hut Bay and Chouldari benefitting the villages in and around that area.

\section{Methodology for Preparation of Potential Linked Credit Plans (PLPs)}

Potential Linked Credit Plan is a comprehensive documentation of potentials in the district for rural economic activities, both in physical and financial terms. It is also an assessment of the gaps in infrastructure support which need to be filled in to fully exploit the realizable potentials.

\section{METHODOLOGY}

NABARD, in 1988-89, took initiative of preparing PLPs for agriculture and rural development. The broad strategy followed by NABARD for the formulation of PLPs envisages estimation of long term potential (in terms of physical units) in each sector of agriculture and rural development with reference to the natural and human resource endowments and a phased annual programme for development, keeping in view the relative national and state priorities. NABARD has been constantly endeavoring to introduce refinements in the methodology of preparing PLPs and improvement of its contents so that the 
PLPs could be used as support reference document for Annual Credit Plans of banks. NABARD has been reviewing continuously the methodology in estimation of potential through consultative process over the years. It adopts a detailed methodology for assessing the physical potential in major sectors of investment activity conducive to development of agriculture and rural areas.

\section{Credit Potential for Agriculture 2021-22 Farm Credit}

The Union Territory of Andaman \& Nicobar has only one agro climatic zone i.e. Island Zone. The topography is undulating and climate is congenial for plantation crops like coconut, arecanut and horticultural crops like tropical fruits, root crops and spices. Almost 4206 ha of land had permanently submerged due to Tsunami during 2004. Out of the total geographical area of 8,24,900 ha of land, approximately less than 40,000 ha land is available for cultivation. The soil of A\&N islands are heterogeneous in nature ranging from Sandy to Heavy Clay type and has low moisture retention capacity. Soil fertility is low due to leaching of nutrients and the soil is acidic in nature, which leads to low productivity. Agriculture is important to the UT of A \& N Islands, as it is for the Indian economy as a whole, for both income and food security. Its importance in these islands has a special bearing to it because of limitation on alternate livelihood possibilities and because of its dependence on mainland for many essential food items.

\section{Assessment of Credit Potential for financial year 2021- 22:}

The credit potential for Farm Credit - Crop Production, Maintenance and Marketing is assessed at Rs.12707.65 Lakh for the FY 2021-22.

\begin{tabular}{|c|c|c|c|c|c|c|}
\hline \multicolumn{7}{|c|}{ (Rs.Lakh) } \\
\hline $\begin{array}{l}\text { Sl. } \\
\text { No. }\end{array}$ & Activity & $\begin{array}{l}\text { Unit (No./ } \\
\text { Area) }\end{array}$ & $\begin{array}{l}\text { Unit } \\
\text { Cost }\end{array}$ & $\begin{array}{l}\text { Physical } \\
\text { Unit }\end{array}$ & $\begin{array}{l}\text { Total Financial } \\
\text { Outlay }\end{array}$ & $\begin{array}{l}\text { Bank } \\
\text { Loan }\end{array}$ \\
\hline 1. & Paddy (HYV) & $\mathrm{Ha}$ & 0.68 & 513 & 348.84 & 348.84 \\
\hline 2. & Paddy (Traditional) & $\mathrm{Ha}$ & 0.64 & 1146 & 733.44 & 733.44 \\
\hline 3. & Pulses & $\mathrm{Ha}$ & 0.47 & 366 & 172.02 & 172.02 \\
\hline 4. & Oilseeds & $\mathrm{Ha}$ & 0.73 & 48 & 35.04 & 35.04 \\
\hline 5. & Vegetables (exotic varieties) & $\mathrm{Ha}$ & 1.96 & 1050 & 2058.00 & 2058.00 \\
\hline 6. & Vegetables (Traditional) & $\mathrm{Ha}$ & 2.00 & 1650 & 3300.00 & 3300.00 \\
\hline 7. & Maintenance of Coconut (175 plants/ ha) & $\mathrm{Ha}$ & 1.25 & 750 & 937.50 & 937.50 \\
\hline 8. & Maintenance of Arecanut (1100 plants/ha) & $\mathrm{Ha}$ & 2.03 & 735 & 1492.05 & 1492.05 \\
\hline & Sub Total & & & & 9076.89 & 9076.89 \\
\hline & $\begin{array}{l}\text { Post Harvest/household/ consumption requirements } \\
\text { (10\% of total crop loan) }\end{array}$ & & & & 907.69 & 907.69 \\
\hline & $\begin{array}{l}\text { Repairs \& maintenance expenses of farm assets (20\% } \\
\text { of total crop loan) }\end{array}$ & & & & 1789.77 & 1789.77 \\
\hline & Marketing of crops( $10 \%$ of total crop loan) & & & & 933.30 & 933.30 \\
\hline & Grand Total & & & & 12707.65 & 12707.65 \\
\hline
\end{tabular}

Credit potential for Small \& Marginal Farmers@10\% of the Potential assessed.

\section{Agriculture Infrastructure Land Development}

Land is prime requirement for undertaking any kind of production activity. Hence development of land is very crucial for agriculture and needs adequate attention for maintaining good soil health. Land development comprises all type of activities undertaken by farmers to improve productivity of land to prevent erosion and improve quality.

The undulating topography of the A \& $\mathrm{N}$ Islands and high annual average rainfall of $3180 \mathrm{~mm}$ causes heavy soil erosion. Soil conservation work is costly and cultivators of the island are not in a position to undertake these works on their own. Further inundation of agriculture lands by sea water due to tsunami, permanent submergence of 4206 ha of cultivable land, increasing salinity level due to poor drainage are areas of concern calling for concerted attention for the development of 
this sector. Most of the hilly land allotted to the cultivators are remaining as waste land or uncultivated.
Assessment of Credit Potential for 2021-

22:

Ground Level Credit (GLC) under the sector is included under Agriculture allied sector in ACP. The credit potential for Land Development is assessed at Rs.126.46 lakh for the FY 2021-22.

\begin{tabular}{|l|l|l|l|l|l|l|}
\hline Sl. No. & \multirow{2}{*}{ Activities } & \multirow{2}{*}{ Unit } & \multirow{2}{*}{ Unit Cost } & PLP Projections 2021-22 \\
\cline { 5 - 7 } & & & & Physical Units & Financial Outlay & Bank Loan \\
\hline 1 & Soil Conservation & ha & 0.35 & 105 & 36.75 & 33.08 \\
\hline 2 & Land Shaping & ha & 0.49 & 96 & 47.04 & 42.34 \\
\hline 3 & Drainage & ha & 0.26 & 92 & 23.92 & 21.53 \\
\hline 4 & Land Reclamation & ha & 0.40 & 82 & 32.80 & 29.52 \\
\hline & & & & 140.51 & 126.46 \\
\hline
\end{tabular}

\section{CONCLUSION}

The parliament created the NABARD act and the Apex bank in order to aid the rural farmers that had long been neglected by the Government. There was such an imitative to uplift industries and capital market that these agricultural sectors were being grossly neglected. Even the apex bank of the country the Reserve Bank of India was so knee deep in other responsibilities and duties that it could not give adequate assistance to the rural farmer and their population which mostly comprised of artisans, small business owners and small other small enterprises. There was a need of adequate funding to these sectors in order for them to develop and flourish like the other sectors that the Indian Government was giving undivided attention to. Thus, this led to the formation of the Rural Apex bank now known as NABARD. The apex rural bank was able to form the relation between credit deliverance and the agricultural sector.

The rural bank has been successful in creating multiple funds and schemes in order to aid the rural farmer. The essential point to note here is that the bank not only facilitates the funding to the farmer but also makes them self sufficient by training personnel in order to better understand modern techniques of farming which only propagates the growth and development relating to rural economies. With the help of the RBI the apex rural bank is also responsible for formulating policies to further benefit the agricultural farmers and the rural poor.

The bank realizes the potential of the agricultural sector and terms non credit worthy farmers as credit worthy ones, these farmers were long rejected by other financial institutions due to the lack of guarantee on their credit. But recent statistics will show that the farmers have lived up to the confidence instilled in them and are actually creating profit and are now operating hassle free when it comes to financing their activities. Various schemes and funds allow farmers to innovate and create new methods and inventions that help them in their field and this is solely because of the investments done by the rural bank.

Acknowledgement: None

Conflict of Interest: None

\section{Source of Funding: None}

\section{REFERENCES}

1. Misra, S.K. \& Puri, V.K. (2010) "Indian Economy”, Himalaya Publishing House Mumbai.

2. A.S. Chawala, K.K. Uppal, Keshav Malhotra (1988), 'Emerging issues in priority sector financing', Indian Banking towards $21^{\text {st }}$ century, Deep and Deep Publication.

3. www.nabard.org.

4. NABARD Complex, Kamaraj Road (VIP Road) Junglighat (P.O), Port Blair-744103, Andaman and Nicobar. 
5. Subbarao Duvvuri (2012) Agricultural Credit Accomplishments and challenges, Speech delivered at NABARD, July 12, 2012.

6. Binswanger,H., Khandker, S. (1992). The Impact of Formal Finance on the Rural Economy of India, WPS 949, Agricultural and Rural Development Department.

7. Zubair, M. (2006). Women empowerment through Micro-credit. In A,Gandhi.(Ed.), Women's Work, health and empowerment. New Delhi, India: Aakar Books.
8. Statistical Tables Relating to Banks in India (Various Issues), Reserve Bank of India. (www.rbl.org.in)

9. Barry, N. (1995). The Missing Links: Financial System that Works for the Majority, Women's World Banking, New York.

How to cite this article: Das M. National bank for agriculture and rural development (NABARD). International Journal of Research and Review. 2021; 8(12): 75-82. DOI: https://doi.org/10.52403/ijrr.20211211 